\title{
Synthesis of Bisimidazole Derivatives for Selective Sensing of Fluoride Ion
}

\author{
Liang Zhang * (D) and Fang Liu \\ School of Material Science and Engineering, Yancheng Institute of Technology, \\ Yancheng 224051, Jiangsu, China; lf@ycit.cn \\ * Correspondence: zhangliang@ycit.edu.cn
}

Received: 10 August 2017; Accepted: 9 September 2017; Published: 11 September 2017

\begin{abstract}
Rapid and efficient analysis of fluoride ion is crucial to providing key information for fluoride ion hazard assessment and pollution management. In this study, we synthesized one symmetrical structure called 1,4-bis(4,5-diphenyl$1 H$-imidazol-2-yl)benzene (1a) and two asymmetrical structures, namely 2-(4-(4,5-diphenyl$1 H$-imidazol-2-yl)phenyl)- $1 H$-phenanthro(9,10-d)imidazole (1) $)$ and 2-(4-(4,5-diphenyl-1H-imidazol2-yl)phenyl)- $1 H$-imidazo $(4,5-f)(1,10)$ phenanthroline (1c), which served as an efficient anion sensor for fluoride ion over a wide range of other anions $\left(\mathrm{Cl}^{-}, \mathrm{Br}^{-}, \mathrm{I}^{-}, \mathrm{NO}_{3}^{-}, \mathrm{ClO}_{4}^{-}, \mathrm{HSO}_{4}{ }^{-}, \mathrm{BF}_{4}^{-}\right.$, and $\mathrm{PF}_{6}{ }^{-}$) owing to imidazole group in the main backbone. The absorption intensity of compound 1a at $\lambda_{\max } 358 \mathrm{~nm}$ slightly decreased; however, a new band at $\lambda_{\max } 414 \mathrm{~nm}$ appeared upon the addition of fluoride ion, while no evident change occurred upon the addition of eight other anions. The photoluminescence intensity of compound $1 \mathrm{a}$ at $\lambda_{\max } 426 \mathrm{~nm}$ was nearly quenched and fluorescence emission spectra were broadened when fluoride ion was added into dimethyl sulfoxide (DMSO) solution of compound 1a. Compared with the optical behaviors of the DMSO solution of compound $1 \mathbf{a}$ in the presence of $\mathrm{Bu}_{4} \mathrm{~N}^{+} \mathrm{F}^{-}$, compounds $\mathbf{1 b}$ and $\mathbf{1 c}$ exhibited considerable sensitivity to fluoride ion due to the increase in coplanarity. Furthermore, compared with the fluorescence emission behaviors of the DMSO solutions of compounds $1 \mathbf{a}$ and $\mathbf{1 b}$ in the presence of $\mathrm{Bu}_{4} \mathrm{~N}^{+} \mathrm{F}^{-}$, compound 1c exhibited the most significant sensitivity to fluoride ion due to the charge transfer enhancement. Consequently, the detection limits of compounds 1a-1c increased from $5.47 \times 10^{-6} \mathrm{M}$ to $4.21 \times 10^{-6}$ $\mathrm{M}$ to $9.12 \times 10^{-7} \mathrm{M}$. Furthermore, the largest red shift $(75 \mathrm{~nm})$ of the DMSO solution compound $1 \mathrm{c}$ in the presence of fluoride ion can be observed. Our results suggest that the increase in coplanarity and the introduction of electron-withdrawing groups to the imidazole backbone can improve the performance in detecting fluoride ion.
\end{abstract}

Keywords: imidazole; fluorescene; phenanthroline; fluoride ion; anion sensor

\section{Introduction}

The field of anion recognition and sensing has attracted considerable attention in the past decades because different anions play different functions in biological and environmental processes and either inadequate or excessive anions would be harmful [1-12]. Among all anions, fluoride ion has been extensively studied because it plays a vital role in medicine, biology, and environmental sciences [13-25]. Therefore, an efficient analysis of fluoride ion is crucial to providing key information for fluoride ion hazard assessment and pollution management. Many groups have made substantial efforts to design and synthesize optical sensors of fluoride ion in recent years [26-32]. Among these optical sensors, imidazole-based optical sensors have been extensively investigated because these sensors are easily obtained and exhibit distinctive fluorescence property and strong interaction between $\mathrm{N}-\mathrm{H}$ fragment and fluoride ion [33-40]. 
In this study, we synthesized one symmetrical structure called 1,4-bis(4,5-diphenyl$1 H$-imidazol-2-yl)benzene (1a) and two asymmetrical structures, namely 2-(4-(4,5diphenyl-1H-imidazol-2-yl)phenyl)- $1 H$-phenanthro(9,10-d)imidazole (1b) and 2-(4-(4,5-diphenyl$1 H$-imidazol-2-yl)phenyl)-1H-imidazo $(4,5-f)(1,10)$ phenanthroline $(\mathbf{1 c})$, which have been further used as optical sensors for fluoride ion. The relationship between molecular structures and optical properties for the analysis of fluoride ion has been investigated in terms of five aspects: (1) Compared with mono-imidazole derivatives, the fluorescence quantum yields of bisimidazole are higher; (2) In view of the influence of molecular rigidity on optical performance for the analysis of fluoride ion, two adjacent phenyl rings are connected through $\mathrm{C}-\mathrm{C}$ bond to increase molecular coplanarity; (3) The introduction of two $\mathrm{sp}^{2}$-hybridized $N$ atoms as electron-withdrawing substituents into the molecular backbone is intended for the investigation of the electronic effects of substituents; (4) As shown in Scheme S2 (Supplementary Materials), compared with compound 1a, compound $\mathbf{1 b}$ exhibits better coplanarity which is more favorable for carrier transport and then improves the detection limit of sensors. Phenanthrene group was used as an electron donor in compound $\mathbf{1} \mathbf{b}$ and then charge transfer can easily occur from phenanthrene group (donor) to imidazole group (acceptor). However, when phenanthrene group is changed to 1,10-phenanthroline group, charge transfer cannot easily occur from 1,10-phenanthroline group to imidazole group because 1,10-phenanthroline group is an stronger electron accepor, compared with imidazole group; (5) When compounds 1a-1c dimethyl sulfoxide (DMSO) solution are added with excess fluoride ion, deprotonation of imidazole group occur which changes imidazole group as an electron donor to as an electron acceptor [33,41], leading to different charge transfer process of compounds $\mathbf{1 b}$ and $\mathbf{1 c}$. Thus, the optical properties of compounds $\mathbf{1 a}-\mathbf{1} \mathbf{c}$ DMSO solution for the analysis of fluoride ion influenced by the molecular structures and electronic properties of substitute groups are investigated in detail.

\section{Results and Discussion}

\subsection{Synthesis of Compounds $\mathbf{1 a}-\mathbf{1} \mathbf{c}$}

Scheme 1 depicts the synthetic procedure for the preparation of compounds $\mathbf{1 a}-\mathbf{1 c}$ according to previous studies [42,43]. The two adjacent phenyl rings of compound 1a were connected through $\mathrm{C}-\mathrm{C}$ bond to form compound $\mathbf{1 b}$, which exhibited a rigid structure and high degree of coplanarity, to investigate the relationship between molecular structures and optical behaviors. Furthermore, two $\mathrm{sp}^{2}$-hybridized $N$ atoms as electron-withdrawing substituents were introduced into compound $\mathbf{1 b}$ to form compound 1c to study the electronic effects of substituents. Consequently, compound 1a displayed a symmetrical structure, whereas compounds $\mathbf{1 b}$ and $\mathbf{1} \mathbf{c}$ had an asymmetrical structure.

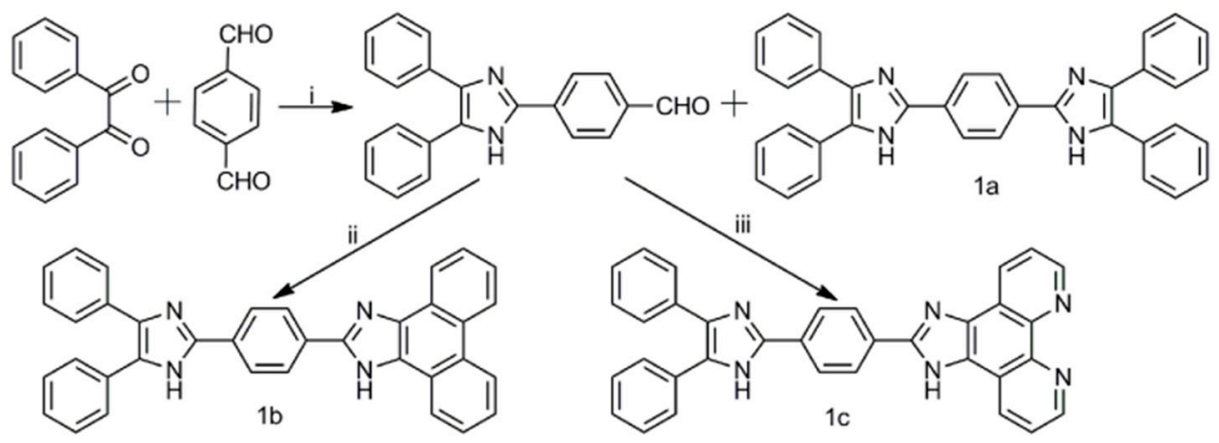

Scheme 1. Synthetic route of compounds 1a-1c. (i) ammonium acetate, glacial acetic acid; (ii) ammonium acetate, glacial acetic acid, phenanthrene-9,10-dione; (iii) ammonium acetate, glacial acetic acid, 1,10-phenanthroline-5,6-dione. 


\subsection{Optical Properties of Compounds 1a-1c}

Figure 1a illustrates the normalized absorption spectra of compounds 1a-1c in DMSO solution. The absorption spectrum of compound 1a exhibits two prominent bands at $\lambda_{\max } 296 \mathrm{~nm}$ and $358 \mathrm{~nm}$, which can be ascribed to a localized aromatic $\pi-\pi^{*}$ transition and the absorption of the entire molecule, respectively [3,33]. Compared with the absorption spectrum of compound 1a, the long peak of compound $\mathbf{1 b}$ is red shifted from $358 \mathrm{~nm}$ to $372 \mathrm{~nm}$ with two shoulder peaks at $\lambda_{\max } 352 \mathrm{~nm}$ and $390 \mathbf{n m}$ because the structure of compound $\mathbf{1 b}$ is more coplanar than that of compound $\mathbf{1 a}$ due to the inhibition of $\mathrm{C}-\mathrm{C}$ single bond rotation of compound $\mathbf{1 b}$. Although compound 1c possesses two $\mathrm{sp}^{2}$-hybridized $N$ atoms as electron-withdrawing substituents, the long peak of compound 1c is slightly blue shifted from $372 \mathrm{~nm}$ (the absorption peak of compound $\mathbf{1 b}$ ) to $367 \mathrm{~nm}$ with a shoulder peak at $\lambda_{\max } 385 \mathrm{~nm}$. This phenomenon is similar to that presented in a previous report regarding symmetrical bisimidazole systems [44]. Molar absorption coefficients of compounds 1a-1c are $6.0 \times 10^{4}$, $5.2 \times 10^{4}$, and $5.2 \times 10^{4} \mathrm{~L} \mathrm{~mol}^{-1} \mathrm{~cm}^{-1}$, respectively. Compounds $1 \mathrm{a}-1 \mathrm{c}$ emit a strong blue light in the DMSO solution, and corresponding emission spectra are shown in Figure 1b. As shown in Figure 1b, two emission bands exist at $\lambda_{\mathrm{em}}=406 \mathrm{~nm}$ and $\lambda_{\mathrm{em}}=426 \mathrm{~nm}$ under excitation at $\lambda_{\mathrm{ex}} 358 \mathrm{~nm}$ for compound 1a, $\lambda_{\mathrm{em}}=416 \mathrm{~nm}$ and $\lambda_{\mathrm{em}}=436 \mathrm{~nm}$ under excitation at $\lambda_{\mathrm{ex}} 372 \mathrm{~nm}$ for compound 1b, and $\lambda_{\mathrm{em}}=438 \mathrm{~nm}$ under excitation at $\lambda_{\mathrm{ex}} 367 \mathrm{~nm}$ for compound 1c. The long emission wavelength is red shifted from compound $\mathbf{1 a}$ to compound $\mathbf{1 b}$ to compound $\mathbf{1 c}$ due to the increase in coplanarity, which can lead to the expansion of the $\pi$ electron delocalization.

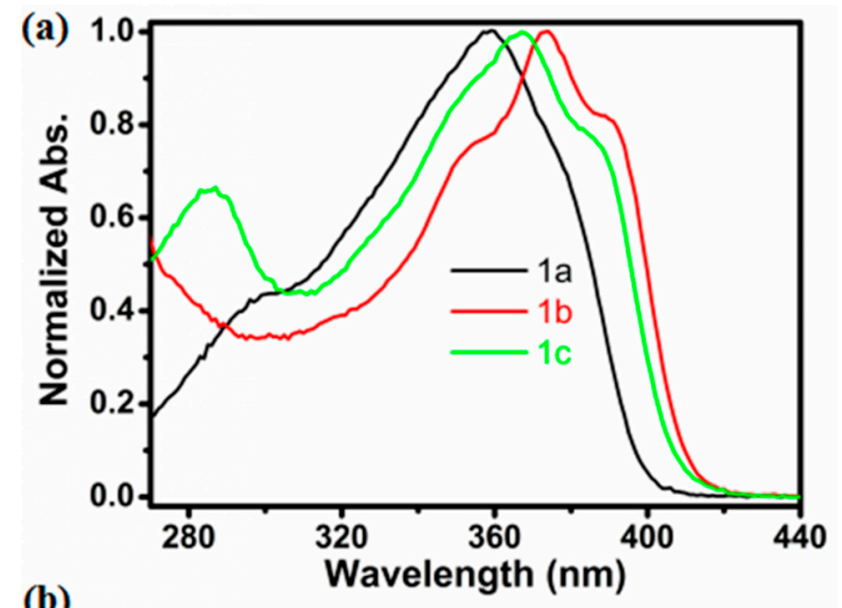

(b)

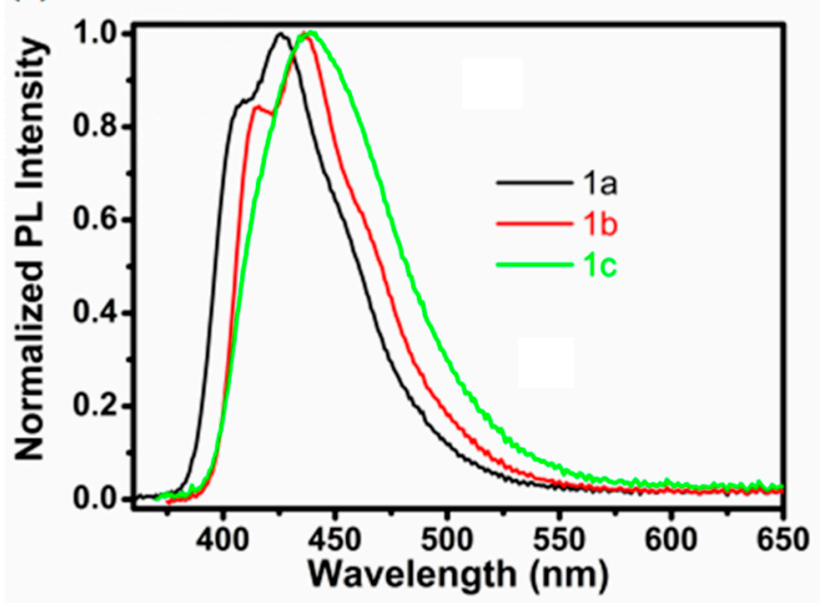

Figure 1. (a) Normalized absorption and (b) emission spectra of compounds 1a-1c in DMSO solution $\left(\lambda_{\mathrm{ex}}=\lambda_{\mathrm{abs}}, 10^{-5} \mathrm{~mol} \mathrm{~L}^{-1}\right)$. 
Although imidazole derivatives have been used as chemosensors for fluoride ion, systematic studies on the effects of coplanarity and electron-withdrawing substituents have rarely been reported. Figure 2a exhibits the absorption spectra of the DMSO solution of compound $1 \mathrm{a}$ in the presence of nine anions $\left(\mathrm{F}^{-}, \mathrm{Cl}^{-}, \mathrm{Br}^{-}, \mathrm{I}^{-}, \mathrm{NO}_{3}{ }^{-}, \mathrm{ClO}_{4}{ }^{-}, \mathrm{HSO}_{4}{ }^{-}, \mathrm{BF}_{4}{ }^{-}\right.$, and $\mathrm{PF}_{6}{ }^{-}, 20$ equiv.). The absorption intensity at $\lambda_{\max } 358 \mathrm{~nm}$ slightly decreases, but a new band at $\lambda_{\max } 414 \mathrm{~nm}$ appears, while no evident change occurred upon the addition of eight other anions. The new band at $\lambda_{\max } 414 \mathrm{~nm}$ is attributed to the variations of the electronic transition due to the occurrence of a strong interaction between fluoride ion and $\mathrm{N}-\mathrm{H}$ groups. As shown in Scheme 2, the imidazole group serves as an electron acceptor before the addition of $\mathrm{Bu}_{4} \mathrm{~N}^{+} \mathrm{F}^{-}$, but the imidazole group acts as an electron donor after the addition of $\mathrm{Bu}_{4} \mathrm{~N}^{+} \mathrm{F}^{-}$, which leads to the charge transfer enhancement. The titration absorption spectra of the DMSO solution of compound $1 \mathrm{a}$ with the addition of different amounts of $\mathrm{Bu}_{4} \mathrm{~N}^{+} \mathrm{F}^{-}$have been examined to verify this phenomenon, as shown in Figure $2 d$. The absorption intensity at $\lambda_{\max } 358 \mathrm{~nm}$ decreases, and the absorption intensity at $\lambda_{\max } 414 \mathrm{~nm}$ steadily increases with the increase in the amount of $\mathrm{Bu}_{4} \mathrm{~N}^{+} \mathrm{F}^{-}$. Meanwhile, the absorption peak at $\lambda_{\max } 358 \mathrm{~nm}$ is red shifted to $378 \mathrm{~nm}$ when 100 equiv. $\mathrm{Bu}_{4} \mathrm{~N}^{+} \mathrm{F}^{-}$is added into the DMSO solution of compound 1a, suggesting that compound 1a can be a candidate as a chemosensor for fluoride ion. The absorption behavior of the DMSO solution of compound $\mathbf{1 b}$ in the presence of $\mathrm{Bu}_{4} \mathrm{~N}^{+} \mathrm{F}^{-}$is similar to that of the DMSO solution of compound 1a. However, a new band at $\lambda_{\max } 420 \mathrm{~nm}$ can be easily observed. Compared with the absorption behaviors of the DMSO solutions of compounds $\mathbf{1 a}$ and $\mathbf{1 b}$ in the presence of $\mathrm{Bu}_{4} \mathrm{~N}^{+} \mathrm{F}^{-}$, the absorption behavior of the DMSO solution of compound $1 \mathrm{c}$ is different to some extent. The absorption peak at $\lambda_{\max } 367 \mathrm{~nm}$ is red shifted with the increase in the amount of $\mathrm{Bu}_{4} \mathrm{~N}^{+} \mathrm{F}^{-}$.
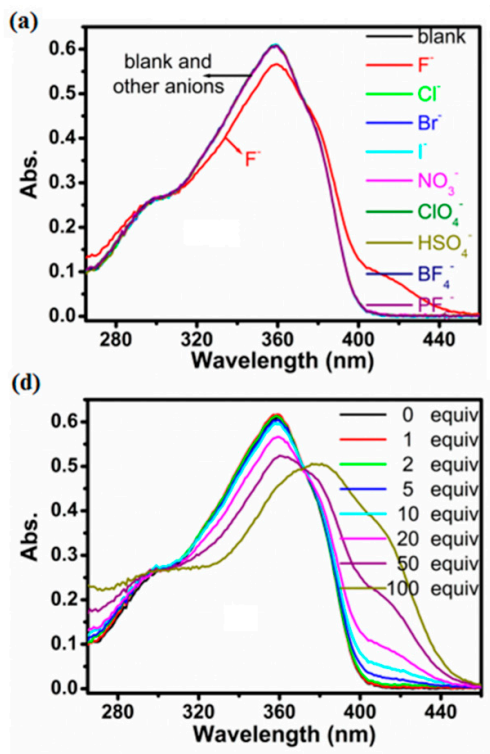

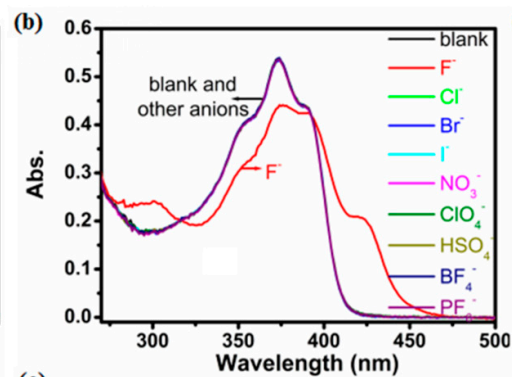

(e)

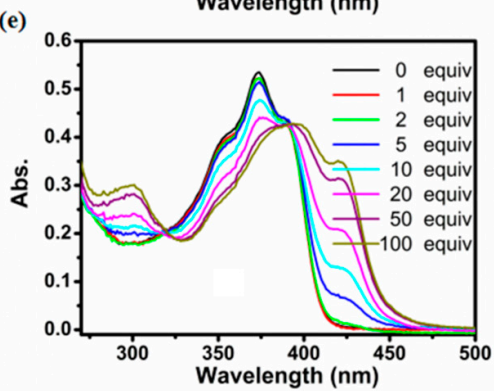

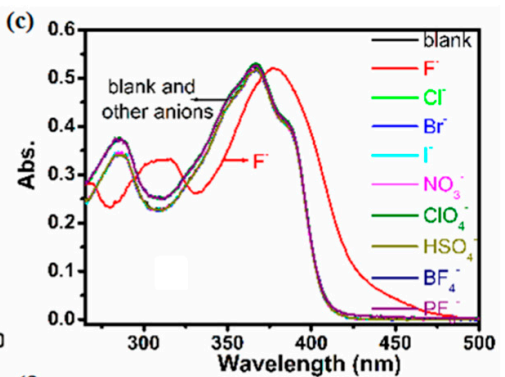

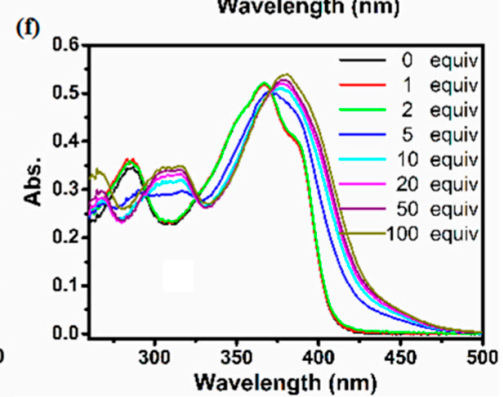

Figure 2. UV/Vis absorption spectra of DMSO solutions of (a) compound $\mathbf{1 a}$; (b) compound 1b; and (c) compound $1 \mathrm{c}\left(10^{-5} \mathrm{~mol} \mathrm{~L}{ }^{-1}\right)$ in the absence (blank) and presence of nine anions (20 equiv.). UV/Vis absorption spectra of DMSO solutions of (d) compound 1a; (e) compound 1b; and (f) compound $1 \mathrm{c}\left(10^{-5} \mathrm{~mol} \mathrm{~L}^{-1}\right)$ with different amounts of $\mathrm{Bu}_{4} \mathrm{~N}^{+} \mathrm{F}^{-}$. 


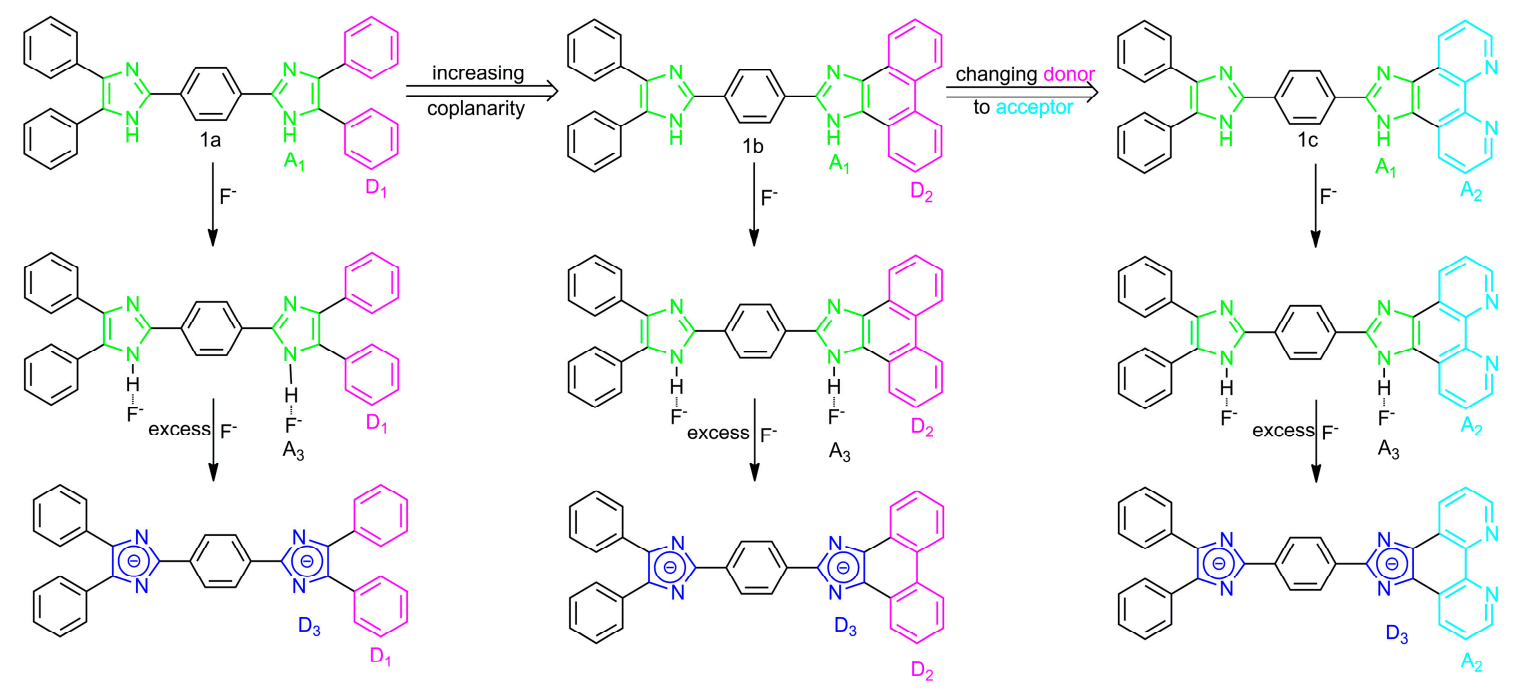

Scheme 2. Schematic diagram for electron transfer process of compounds 1a-1c in the presence of $\mathrm{Bu}_{4} \mathrm{~N}^{+} \mathrm{F}^{-}(\mathrm{A}=$ electron acceptor; $\mathrm{D}=$ electron donor $)$.

The fluorescence emission behaviors of the DMSO solutions of compounds $1 \mathrm{a}-\mathbf{1} \mathbf{c}$ in the presence of nine anions $\left(\mathrm{F}^{-}, \mathrm{Cl}^{-}, \mathrm{Br}^{-}, \mathrm{I}^{-}, \mathrm{NO}_{3}{ }^{-}, \mathrm{ClO}_{4}{ }^{-}, \mathrm{HSO}_{4}{ }^{-}, \mathrm{BF}_{4}^{-}\right.$, and $\mathrm{PF}_{6}{ }^{-}, 20$ equiv.) are also investigated, and the corresponding emission spectra are shown in Figure 3. As shown in Figure $3 a, d$, the photoluminescence (PL) intensity of compound 1a is slightly quenched, and the fluorescence emission spectra are slightly broadened in the presence of fluoride ion (20 equiv.), while no evident fluorescence change occurred in the presence of eight other anions. Figure $3 \mathrm{~g}$ depicts the titration emission spectra of the DMSO solution of compound $1 \mathrm{a}$ with the addition of different amounts of $\mathrm{Bu}_{4} \mathrm{~N}^{+} \mathrm{F}^{-}$. The PL intensity at $\lambda_{\max } 426 \mathrm{~nm}$ is nearly quenched, and the fluorescence emission spectra are further broadened when 100 equiv. $\mathrm{Bu}_{4} \mathrm{~N}^{+} \mathrm{F}^{-}$are added into the DMSO solution of compound 1a. The UV/Vis absorption and fluorescence emission spectra of compound 1a shows a fact that firstly formation of $\mathrm{N}-\mathrm{H} \cdots$ F hydrogen bond and subsequent deprotonation with adding excess $\mathrm{Bu}_{4} \mathrm{~N}^{+} \mathrm{F}^{-}$is responsible for the behaviour of compound 1a (Scheme 2). Figure S11 shows that the linear regression equation of compound 1a was $y=4.781-0.00347 x$, and the slope was -0.00347 (Supplementary Materials). The detection limit of compound 1a was calculated to be $5.47 \times 10^{-6} \mathrm{M}$ with the equation: detection limit $=3 S_{d} / \varrho$, where $S_{d}$ is the standard deviation of blank measurement, and $\varrho$ is the slope between the fluorescence intensity versus fluoride ion concentration $[45,46]$. The emission behavior of the DMSO solution of compound $\mathbf{1 b}$ in the presence of $\mathrm{Bu}_{4} \mathrm{~N}^{+} \mathrm{F}^{-}$is similar to that of the DMSO solution of compound 1a. However, the PL intensity of compound $\mathbf{1 b}$ is quenched, and a new band at $\lambda_{\max }$ $470 \mathrm{~nm}$ appears in the presence of fluoride ion (20 equiv.). The detection limit of compound $\mathbf{1 b}$ was calculated to be $4.21 \times 10^{-6} \mathrm{M}$ according to Figure S12. Compared with the emission behaviors of the DMSO solutions of compounds $\mathbf{1 a}$ and $\mathbf{1 b}$ in the presence of $\mathrm{Bu}_{4} \mathrm{~N}^{+} \mathrm{F}^{-}$, the emission behavior of the DMSO solution of compound $\mathbf{1} \mathbf{c}$ is different. The PL intensity of compound $1 \mathrm{c}$ at $\lambda_{\max } 438 \mathrm{~nm}$ is dramatically quenched, and a new band at $\lambda_{\max } 513 \mathrm{~nm}$ is easily observed in the presence of fluoride ion (20 equiv.). Furthermore, the PL peak of compound $1 \mathrm{c}$ at $\lambda_{\max } 438 \mathrm{~nm}$ disappears when 50 equiv. $\mathrm{Bu}_{4} \mathrm{~N}^{+} \mathrm{F}^{-}$are added into the DMSO solution of compound 1c. The detection limit of compound $1 \mathrm{c}$ was calculated to be $9.12 \times 10^{-7} \mathrm{M}$ according to Figure S13. As shown in Scheme 2, the imidazole group acts as as an electron acceptor before the addition of $\mathrm{Bu}_{4} \mathrm{~N}^{+} \mathrm{F}^{-}$, charge transfer can easily occur from diphenyl (for compound 1a) or phenanthrene (for compound $\mathbf{1 b}$ ) group (donor) to imidazole group (acceptor) but charge transfer can not easily occur from 1,10-phenanthroline group (for compound 1c) to imidazole group because 1,10-phenanthroline group is an stronger electron accepor. While the imidazole group acts an electron donor after the addition of excess $\mathrm{Bu}_{4} \mathrm{~N}^{+} \mathrm{F}^{-}$, which leads to the charge 
transfer enhancement from the imidazole group to 1,10-phenanthroline. Therefore, the largest red shift (75 nm) of the DMSO solution of compound 1c is in the presence of $\mathrm{Bu}_{4} \mathrm{~N}^{+} \mathrm{F}^{-}$.
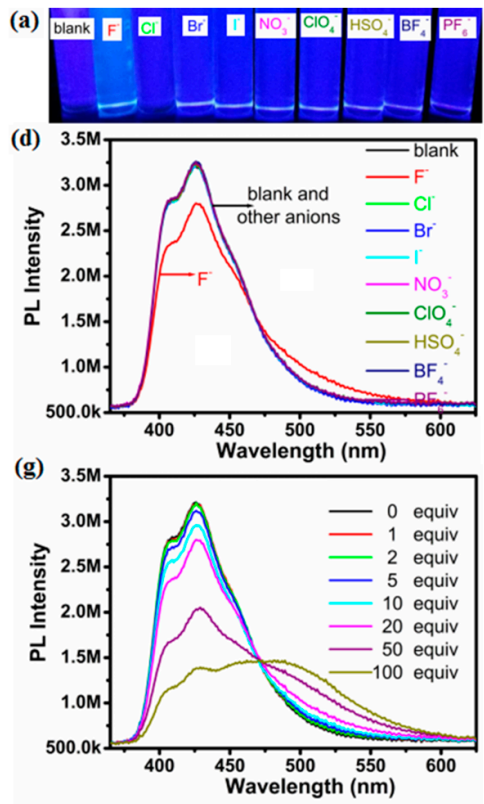

(b)

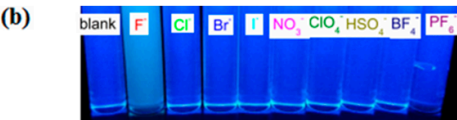

(e)
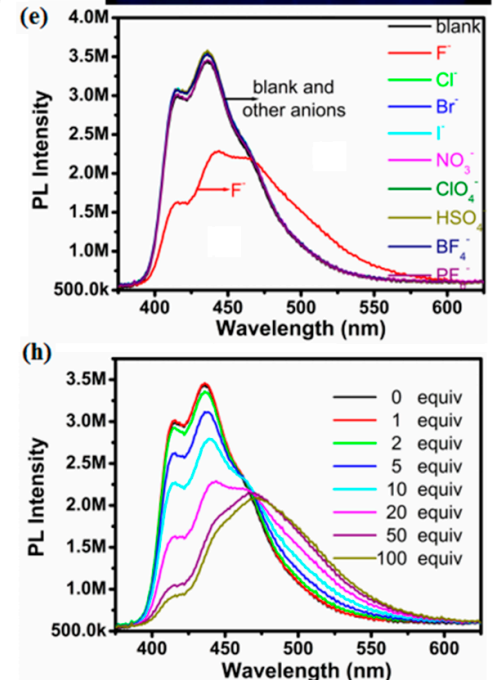

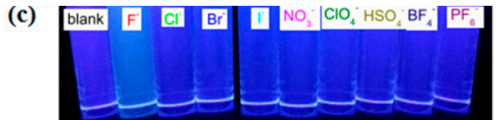

(f)
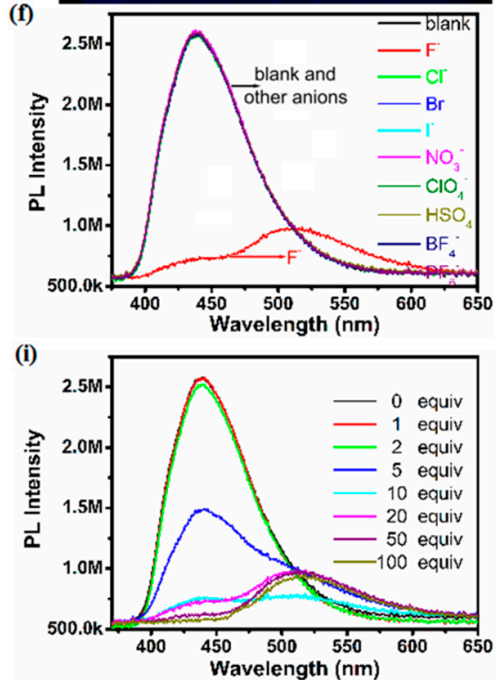

Figure 3. Photographs of the DMSO solutions of (a) compound 1a; (b) compound 1b; and (c) compound $1 \mathrm{c}\left(10^{-5} \mathrm{~mol} \mathrm{~L}^{-1}\right)$ in the absence (blank) and presence of nine anions (20 equiv.) taken under UV light at $365 \mathrm{~nm}$. Emission spectra of DMSO solutions of (d) compound 1a; (e) compound $\mathbf{1 b}$, and (f) compound $1 \mathbf{c}\left(10^{-5} \mathrm{~mol} \mathrm{~L}^{-1}\right)$ in the absence (blank) and presence of nine anions (20 equiv.). UV/Vis absorption spectra of DMSO solutions of (g) compound 1a; (h) compound $\mathbf{1 b}$; and (i) compound $1 \mathrm{c}\left(10^{-5} \mathrm{~mol} \mathrm{~L}-1\right)$ with different amounts of $\mathrm{Bu}_{4} \mathrm{~N}^{+} \mathrm{F}^{-}$.

\section{Conclusions}

In summary, one symmetrical structure (1a) and two asymmetric structures (1) and $\mathbf{1 c})$ were successfully synthesized. Interestingly, compounds $\mathbf{1 a}-\mathbf{1 c}$ can act as efficient anion sensors for fluoride ion over a wide range of other anions $\left(\mathrm{Cl}^{-}, \mathrm{Br}^{-}, \mathrm{I}^{-}, \mathrm{NO}_{3}^{-}, \mathrm{ClO}_{4}^{-}, \mathrm{HSO}_{4}^{-}, \mathrm{BF}_{4}^{-}\right.$and $\left.\mathrm{PF}_{6}^{-}\right)$owing to the imidazole group in the main backbone. Compared with the optical behaviors of the DMSO solution of compound $\mathbf{1 a}$ in the presence of $\mathrm{Bu}_{4} \mathrm{~N}^{+} \mathrm{F}^{-}$, compounds $\mathbf{1 b}$ and $\mathbf{1 c}$ exhibit considerable sensitivity to fluoride ion due to the increase in the coplanarity. Furthermore, compared with the fluorescence emission behaviors of the DMSO solutions of compounds $\mathbf{1 a}$ and $\mathbf{1 b}$ in the presence of $\mathrm{Bu}_{4} \mathrm{~N}^{+} \mathrm{F}^{-}$, compound 1c exhibits the most significant sensitivity to fluoride ion due to charge transfer enhancement. Consequently, the detection limits of compounds 1a-1c increase from $5.47 \times 10^{-6} \mathrm{M}$ to $4.21 \times 10^{-6} \mathrm{M}$ to $9.12 \times 10^{-7} \mathrm{M}$. Our results suggest that the increase in the coplanarity and the introduction of electron-withdrawing groups to the imidazole backbone can improve the performance in detecting fluoride ion. We will introduce poly(ethylene glycol) methyl ether into start materials to improve the solubily of target compounds in water in our future work.

Supplementary Materials: Supplementary Materials are available online. Figure S1. ${ }^{1} \mathrm{H}$ NMR spectrum of compound 4-(4,5-diphenyl-1H-imidazol-2-yl)benzaldehyde in DMSO- $d_{6}$. Figure S2. ${ }^{1} \mathrm{H}$ NMR spectrum of compound 1a in DMSO- $d_{6}$. Figure S3. ${ }^{1} \mathrm{H}$ NMR spectrum of compound $\mathbf{1 b}$ in DMSO- $d_{6}$. Figure S4. ${ }^{1} \mathrm{H}$ NMR spectrum of compound 1c in DMSO- $d_{6}$. Figure S5. MS spectrum of compound 1a. Figure S6. MS spectrum of compound 1b. Figure S7. MS spectrum of compound 1c. Figure S8. Correlation curves of compound 1a at $358 \mathrm{~nm}$ and $414 \mathrm{~nm}$ adding different equivalents of $\mathrm{F}^{-}$. Figure S9. Correlation curves of compound $\mathbf{1 b}$ at $372 \mathrm{~nm}$ and $420 \mathrm{~nm}$ adding different equivalents of $\mathrm{F}^{-}$. Figure S10. Correlation curves of compound 1c at $367 \mathrm{~nm}$ and $380 \mathrm{~nm}$ adding different equivalents of $\mathrm{F}^{-}$. Figure S11. Change in PL intensity of compound 1a (10 uM) upon 
titration with $\mathrm{F}^{-}$. Figure S12. Change in PL intensity of compound $\mathbf{1 b}(10 \mathrm{uM})$ upon titration with $\mathrm{F}^{-}$. Figure S13. Change in PL intensity of compound $1 \mathrm{c}(10 \mathrm{uM})$ upon titration with $\mathrm{F}^{-}$.

Author Contributions: Liang Zhang and Fang Liu conceived and designed the experiments and wrote the paper; Liang Zhang reviewed the paper.

Conflicts of Interest: The authors declare no conflict of interest.

\section{References}

1. Descalzo, A.B.; Rurack, K.; Weisshoff, H.; Martínez-Máñez, R.; Marcos, M.D.; Amorós, P.; Hoffmann, K.; Soto, J. Rational design of a chromo- and fluorogenic hybrid chemosensor material for the detection of long-chain carboxylates. J. Am. Chem. Soc. 2005, 127, 184-200. [CrossRef] [PubMed]

2. Vetrichelvan, M.; Nagarajan, R.; Valiyaveettil, S. Carbazole-containing conjugated copolymers as colorimetric/ fluorimetric sensor for iodide anion. Macromolecules 2006, 39, 8303-8310. [CrossRef]

3. Lin, T.-P.; Chen, C.-Y.; Wen, Y.-S.; Sun, S.-S. Synthesis, photophysical, and anion-sensing properties of quinoxalinebis (sulfonamide) functionalized receptors and their metal complexes. Inorg. Chem. 2007, 46, 9201-9212. [CrossRef] [PubMed]

4. Ajayakumar, M.; Mukhopadhyay, P.; Yadav, S.; Ghosh, S. Single-electron transfer driven cyanide sensing: A new multimodal approach. Org. Lett. 2010, 12, 2646-2649. [CrossRef] [PubMed]

5. Eun Jun, M.; Roy, B.; Han Ahn, K. “Turn-on" fluorescent sensing with "reactive" probes. Chem. Commun. 2011, 47, 7583-7601. [CrossRef] [PubMed]

6. Li, X.; Gao, X.; Shi, W.; Ma, H. Design strategies for water-soluble small molecular chromogenic and fluorogenic probes. Chem. Rev. 2014, 114, 590-659. [CrossRef] [PubMed]

7. Busschaert, N.; Caltagirone, C.; Van Rossom, W.; Gale, P.A. Applications of supramolecular anion recognition. Chem. Rev. 2015, 115, 8038-8155. [CrossRef] [PubMed]

8. Ros-Lis, J.V.; Martinez-Manez, R.; Soto, J. Subphthalocyanines as fluoro-chromogenic probes for anions and their application to the highly selective and sensitive cyanide detection. Chem. Commun. 2005, 5260-5262. [CrossRef] [PubMed]

9. Ma, G.; Müller, A.M.; Bardeen, C.J.; Cheng, Q. Self-assembly combined with photopolymerization for the fabrication of fluorescence "turn-on" vesicle sensors with reversible "on-off" switching properties. Adv. Mater. 2006, 18, 55-60. [CrossRef]

10. Garcia, F.; Garcia, J.M.; Garcia-Acosta, B.; Martinez-Manez, R.; Sancenon, F.; Soto, J. Pyrylium-containing polymers as sensory materials for the colorimetric sensing of cyanide in water. Chem. Commun. 2005, 2790-2792. [CrossRef] [PubMed]

11. Yang, C.; Xu, J.; Ma, J.; Zhu, D.; Zhang, Y.; Liang, L.; Lu, M. An efficient long fluorescence lifetime polymer-based sensor based on europium complex as chromophore for the specific detection of $\mathrm{F}^{-}$, $\mathrm{CH}_{3} \mathrm{COO}^{-}$, and $\mathrm{H}_{2} \mathrm{PO}_{4}^{-}$. Polym. Chem. 2012, 3, 2640-2648. [CrossRef]

12. Isaad, J.; Perwuelz, A. New color chemosensors for cyanide based on water soluble azo dyes. Tetrahedron Lett. 2010, 51, 5810-5814. [CrossRef]

13. Zhou, Y.; Zhang, J.F.; Yoon, J. Fluorescence and colorimetric chemosensors for fluoride-ion detection. Chem. Rev. 2014, 114, 5511-5571. [CrossRef] [PubMed]

14. Hu, R.; Feng, J.; Hu, D.; Wang, S.; Li, S.; Li, Y.; Yang, G. A rapid aqueous fluoride ion sensor with dual output modes. Angew. Chem. Int. Ed. 2010, 49, 4915-4918. [CrossRef] [PubMed]

15. Kim, T.H.; Swager, T.M. A fluorescent self-amplifying wavelength-responsive sensory polymer for fluoride ions. Angew. Chem. Int. Ed. 2003, 42, 4803-4806. [CrossRef] [PubMed]

16. Ke, B.; Chen, W.; Ni, N.; Cheng, Y.; Dai, C.; Dinh, H.; Wang, B. A fluorescent probe for rapid aqueous fluoride detection and cell imaging. Chem. Commun. 2013, 49, 2494-2496. [CrossRef] [PubMed]

17. Ambrosi, G.; Formica, M.; Fusi, V.; Giorgi, L.; Macedi, E.; Piersanti, G.; Retini, M.; Varrese, M.A.; Zappia, G. New coumarin-urea based receptor for anions: A selective off-on fluorescence response to fluoride. Tetrahedron 2012, 68, 3768-3775. [CrossRef]

18. Martinez-Manez, R.; Sancenon, F. New advances in fluorogenic anion chemosensors. J. Fluoresc. 2005, 15, 267-285. [CrossRef] [PubMed]

19. Yang, X.-F.; Qi, H.; Wang, L.; Su, Z.; Wang, G. A ratiometric fluorescent probe for fluoride ion employing the excited-state intramolecular proton transfer. Talanta 2009, 80, 92-97. [CrossRef] [PubMed] 
20. Bao, Y.; Liu, B.; Wang, H.; Tian, J.; Bai, R. A "naked eye" and ratiometric fluorescent chemosensor for rapid detection of $\mathrm{F}^{-}$based on combination of desilylation reaction and excited-state proton transfer. Chem. Commun. 2011, 47, 3957-3959. [CrossRef] [PubMed]

21. Sivaraman, G.; Chellappa, D. Rhodamine based sensor for naked-eye detection and live cell imaging of fluoride ions. J. Mater. Chem. B 2013, 1, 5768-5772. [CrossRef]

22. Kim, S.Y.; Park, J.; Koh, M.; Park, S.B.; Hong, J.I. Fluorescent probe for detection of fluoride in water and bioimaging in A549 human lung carcinoma cells. Chem. Commun. 2009, 21, 4735-4737. [CrossRef] [PubMed]

23. Amendola, V.; Bergamaschi, G.; Boiocchi, M.; Fabbrizzi, L.; Mosca, L. The interaction of fluoride with fluorogenic ureas: An ON1-OFF-ON2 response. J. Am. Chem. Soc. 2013, 135, 6345-6355. [CrossRef] [PubMed]

24. Kim, D.; Singha, S.; Wang, T.; Seo, E.; Lee, J.H.; Lee, S.J.; Kim, K.H.; Ahn, K.H. In vivo two-photon fluorescent imaging of fluoride with a desilylation-based reactive probe. Chem. Commun. 2012, 48, 10243-10245. [CrossRef] [PubMed]

25. Lin, Z.H.; Zhao, Y.G.; Duan, C.Y.; Zhang, B.G.; Bai, Z.P. A highly selective chromo- and fluorogenic dual responding fluoride sensor: Naked-eye detection of F- ion in natural water via a test paper. Dalton Trans. 2006, 30, 3678-3684. [CrossRef] [PubMed]

26. Ren, J.; Wu, Z.; Zhou, Y.; Li, Y.; Xu, Z. Colorimetric fluoride sensor based on 1,8-naphthalimide derivatives. Dyes Pigments 2011, 91, 442-445. [CrossRef]

27. Rao, M.R.; Mobin, S.M.; Ravikanth, M. Boron-dipyrromethene based specific chemodosimeter for fluoride ion. Tetrahedron 2010, 66, 1728-1734. [CrossRef]

28. Hou, P.; Chen, S.; Wang, H.; Wang, J.; Voitchovsky, K.; Song, X. An aqueous red emitting fluorescent fluoride sensing probe exhibiting a large Stokes shift and its application in cell imaging. Chem. Commun. 2014, 50, 320-322. [CrossRef] [PubMed]

29. Lu, H.; Wang, Q.; Li, Z.; Lai, G.; Jiang, J.; Shen, Z. A specific chemodosimeter for fluoride ion based on a pyrene derivative with trimethylsilylethynyl groups. Org. Biomol. Chem. 2011, 9, 4558-4562. [CrossRef] [PubMed]

30. Goswami, S.; Das, A.K.; Manna, A.; Maity, A.K.; Fun, H.-K.; Quah, C.K.; Saha, P. A colorimetric and ratiometric fluorescent turn-on fluoride chemodosimeter and application in live cell imaging: High selectivity via specific $\mathrm{SiO}$ cleavage in semi aqueous media and prompt recovery of ESIPT along with the X-ray structures. Tetrahedron Lett. 2014, 55, 2633-2638. [CrossRef]

31. Gu, P.-Y.; Wang, Z.; Zhang, Q. Azaacenes as active elements for sensing and bio applications. J. Mater. Chem. B 2016, 4, 7060-7074. [CrossRef]

32. Gu, P.-Y.; Wang, Z.; Liu, G.; Nie, L.; Ganguly, R.; Li, Y.; Zhang, Q. Synthesis, physical properties, and sensing behaviour of a novel naphthalenediimide derivative. Dyes Pigments 2016, 131, 224-230. [CrossRef]

33. Mahapatra, A.K.; Karmakar, P.; Roy, J.; Manna, S.; Maiti, K.; Sahoo, P.; Mandal, D. Colorimetric and ratiometric fluorescent chemosensor for fluoride ions based on phenanthroimidazole (PI): Spectroscopic, NMR and density functional studies. RSC Adv. 2015, 5, 37935-37942. [CrossRef]

34. Batista, R.M.F.; Oliveira, E.; Costa, S.P.G.; Lodeiro, C.; Raposo, M.M.M. Cyanide and fluoride colorimetric sensing by novel imidazo-anthraquinones functionalised with indole and carbazole. Supramol. Chem. 2013, 26, 71-80. [CrossRef]

35. Kumar, D.; Thomas, K.R.J. 2-Hydroxyarylimidazole-based colorimetric and ratiometric fluoride ion sensors. RSC Adv. 2014, 4, 56466-56474. [CrossRef]

36. Gwon, S.Y.; Kim, S.H. Anion sensing and F(-)-induced reversible photoreaction of D-pi-A type dye containing imidazole moiety as donor. Spectrochim. Acta A 2014, 117, 810-813. [CrossRef] [PubMed]

37. Li, R.; Wang, S.; Li, Q.; Lan, H.; Xiao, S.; Li, Y.; Tan, R.; Yi, T. A fluorescent non-conventional organogelator with gelation-assisted piezochromic and fluoride-sensing properties. Dyes Pigments 2017, 137, 111-116. [CrossRef]

38. Manivannan, R.; Satheshkumar, A.; Elango, K.P. Tuning of the H-bonding ability of imidazole N-H towards the colorimetric sensing of fluoride and cyanide ions as their sodium salts in water. New J. Chem. 2013, 37, 3152-3160. [CrossRef]

39. Jayasudha, P.; Manivannan, R.; Elango, K.P. Highly selective colorimetric receptors for detection of fluoride ion in aqueous solution based on quinone-imidazole ensemble-Influence of hydroxyl group. Sens. Actuator B Chem. 2016, 237, 230-238. [CrossRef] 
40. Jain, A.; Gupta, R.; Agarwal, M. Rationally designed tri-armed imidazole-indole hybrids as naked eye receptors for fluoride ion sensing. Synth. Commun. 2017, 47, 1307-1318. [CrossRef]

41. Gu, P.-Y.; Gao, J.; Zhang, Q.; Liu, G.; Zhou, F.; Xu, Q.-F.; Lu, J.-M. Tuning optical properties of phenanthroline derivatives through varying excitation wavelength and $\mathrm{pH}$ values. J. Mater. Chem. C 2014, 2, 1539-1544. [CrossRef]

42. Tian, M.; Wang, C.; Wang, L.; Luo, K.; Zhao, A.; Guo, C. Study on the synthesis and structure-effect relationship of multi-aryl imidazoles with their fluorescence properties. Luminescence 2014, 29, 540-548. [CrossRef] [PubMed]

43. Gao, F.; Chen, X.; Zhou, F.; Weng, L.-P.; Guo, L.-T.; Chen, M.; Chao, H.; Ji, L.-N. pH responsive luminescent switches of ruthenium(II) complexes containing two imidazole groups: Synthesis, spectroscopy, electrochemistry and theoretical calculations. Inorg. Chim. Acta 2009, 362, 4960-4966. [CrossRef]

44. Xie, N.; Chen, Y. Synthesis and photophysical properties of 1,4-bis(4,5-diarylimidazol) benzene dyes. J. Photochem. Photobiol. A 2007, 189, 253-257. [CrossRef]

45. Hu, J.-Y.; Liu, R.; Zhu, X.-L.; Cai, X.; Zhu, H.-J. A highly efficient and selective probe for $\mathrm{F}^{-}$detection based on $1 H$-imidazo[4,5-b]phenazine derivative. Chin. Chem. Lett. 2015, 26, 339-342. [CrossRef]

46. Niu, H.T.; Su, D.; Jiang, X.; Yang, W.; Yin, Z.; He, J.; Cheng, J.P. A simple yet highly selective colorimetric sensor for cyanide anion in an aqueous environment. Org. Biomol. Chem. 2008, 6, 3038-3040. [CrossRef] [PubMed]

Sample Availability: Samples of the compounds 1a-1c are available from the authors.

(C) 2017 by the authors. Licensee MDPI, Basel, Switzerland. This article is an open access article distributed under the terms and conditions of the Creative Commons Attribution (CC BY) license (http://creativecommons.org/licenses/by/4.0/). 